\title{
Genetic Relationship Among 36 Genotypes of Ceiba pentandra (L.) as Revealed by RAPD and ISSR Markers
}

\author{
Cosmas Sorngmenenye Abengmeneng ${ }^{1, ~ *}$, Daniel Ofori ${ }^{2}$, Philomena Kumapley ${ }^{1}$, Richard Akromah ${ }^{3}$, \\ Ramni Jamnadass ${ }^{4}$, Marian Quain ${ }^{5}$ \\ ${ }^{1}$ Department of Silviculture and Forest Management, Kwame Nkrumah University of Science and Technology, Kumasi, Ghana \\ ${ }^{2}$ Forestry Research Institute of Ghana, Council for Scientific and Industrial Research, Kumasi, Ghana \\ ${ }^{3}$ Department of Crop and Soil Sciences, Kwame Nkrumah University of Science and Technology, Kumasi, Ghana \\ ${ }^{4}$ International Centre for Research into Agroforestry, Nairobi, Kenya \\ ${ }^{5}$ Crop Research Institute, Council for Scientific and Industrial Research, Kumasi, Ghana
}

\section{Email address:}

cosmassabengmeneng@yahoo.com (C. S. Abengmeneng), dofori@csir-forig.org.gh (D. Ofori), perpkumapley@yahoo.com (P. Kumapley), rakromah@yahoo.com (R. Akromah),r.jamnadass@cgiar.org (R. Jamnadass), marianquain@hotmail.com (M. Quain)

${ }^{*}$ Corresponding author

\section{To cite this article:}

Cosmas Sorngmenenye Abengmeneng, Daniel Ofori, Philomena Kumapley, Richard Akromah, Ramni Jamnadass, Marian Quain. Genetic Relationship Among 36 Genotypes of Ceiba pentandra (L.) as Revealed by RAPD and ISSR Markers. American Journal of Agriculture and Forestry. Vol. 4, No. 4, 2016, pp. 86-96. doi: 10.11648/j.ajaf.20160404.13

Received: May 25, 2016; Accepted: June 12, 2016; Published: July 23, 2016

\begin{abstract}
Ceiba pentandra (L.) Gaertn (trade name Ceiba) of the family Bombacaceae is an important multi-purpose tree species in Ghana and demand for it is rising daily. As a result, it has been included as one of the species for the National Forest Plantation Development Programme of Ghana as part of the efforts towards its restoration. Seedlings for the programme are being raised from seed collected from the wild without regard for their genetic quality and its future adverse effects. The absence of adequate information on the genetic diversity within the species therefore serves as a potential threat to its long term sustainable management and efficient genetic conversation. The phylogenetic relationships of 36 genotypes of $C$. pentandra from natural range of the species in five ecological zones (populations) of Ghana were therefore analyzed using 10 polymerase chain reaction (PCR) markers (5 random amplified polymorphic DNAs (RAPDs) and 5 inter simple sequence repeats (ISSRs)). The principal component analysis (PcoA) defined by axis 1 and 2 accounted for $67.15 \%$ of the variation observed. Cluster analysis using GeneStat Discovery showed that, $14(38.89 \%), 21(58.33 \%)$ and $4(11.11 \%)$ of the accessions had a coefficient of similarity of 1 from the RAPD, ISSR and the combined RAPD and ISSR polymorphism respectively. The most distantly related accessions from the RAPD polymorphism analysis were BAW 1 and KON 8 with a similarity coefficient of 0.06 whereas those from the ISSR polymorphism were BAW 10 and ASE 1 with $21 \%$ similarity between them. Similarly, BUF 1 and KUE 1 were the most dissimilar accessions from the combined RAPD and ISSR fragments analysis with a similarity coefficient of 0.23 . Nine (25\%) accessions with high degree of dissimilarity between them were identified in the study. These accessions could serve as good candidates for conservation as seed trees and in breeding programs of $C$. pentandra in Ghana. Implications of the findings for effective management of the genetic resources of the species were also discussed.
\end{abstract}

Keywords: Ceiba pentandra (L.), ISSR, RAPD, Genetic Diversity, Population, Genotypes

\section{Introduction}

Ceiba pentandra (L.) Gaertn, of the family Bombacaceae, is a native species of the natural forests of tropical America and tropical Asia [1, 2, 3]. It is commonly called the silk or kapok tree and is known to have a pantropical distribution [4, 5]. The wood is used in manufacturing plywood, domestic utensils, drums, dugout canoes, and coffins [1,2]. The fibre, commonly called kapok, is used for stuffing cushions, pillows and mattresses. It is also used in insulation, as absorbent material and tinder. The gum is eaten to relieve stomach upset whereas 
the leaves and fruits are used as a laxative and infusion from the leaf for colic treatment in both man and livestock [2]. $C$. pentandra is gradually diminishing due to over exploitation in Ghana and other parts of the world. For instance, populations in the Peruvian and Brazilian Amazon have been reported to be endangered due to over exploitation for plywood [6]. $C$. pentandra has therefore been included as one of the species for the National Forest Plantation Development Programme (NFPDP) of Ghana as part of the efforts to ensure its sustainable management. Seed for raising seedlings for the programme are currently being collected from the wild without regard for their genetic quality. The absence of knowledge on the genetic diversity in the species could have adverse effects on its survival and overall productivity in the future. High levels of genetic variation provide the ability for tree species to adjust to new environments, allowing local adaptation and the migration of better-suited provenances along ecological gradients [7]. As a result, genetic diversity conservation has been designed to conserve the optimum amount of genetic information in the present population for future use [8]. The identification of genetic variation is therefore seen as an essential tool for its conservation and management $[9,10,11]$. Again, genetic diversity is the first basic step in breeding programme and therefore needs to be estimated accurately [12]. DNA fingerprinting is one of the well known methods that is used in the study of the extent of genetic diversity of germplasm or cultivars as well as their specific classification. DNA markers provide a powerful tool to quantify existing levels of genetic variation in breeding and production populations of forest trees [13]. Some of the techniques used particularly when no genetic information is available include RAPD [11, 14, 15, 16] and ISSR [10, 11, 17, 18] and the combined analysis of RAPD and ISSR polymorphisms [11, 19]. MolecularThis study used DNA from progenies to represent parental genotypes using two PCR based techniques; RAPD and ISSR. These techniques are recommended for species in which there is no prior availability of molecular genetic information [11]. C. pentandra is a typical example of this as this study pioneers its molecular work in Ghana. The study has identified the level of genetic diversity among accessions of $C$. pentandra in Ghana as well as genetically unrelated ones for conservation as seed trees.

\section{Materials and Methods}

\subsection{Plant Material Used}

Matured fruits were collected from open-pollinated individual trees (trees in which only one parent; the female, is known) in the natural range of $C$. pentandra in Ghana. These open-pollinated families were referred to as accessions and or mother trees in this paper. An isolation distance of at least 100 metres was allowed between sampled trees to ensure that trees with the same pedigrees were avoided. The seeds were germinated and maintained under shed made from palm fronts and the seedlings transplanted to the field at the age of five months. Fresh leaves were collected from progenies of 36 accessions at twelve months after they were transplanted in the field. The leaves were thoroughly but carefully washed with distilled water and dried with tissue paper to rid off any possible contaminants. A total of $200 \mathrm{mg}$ of fresh leaf were taken using a cork borer. The discs were placed in labelled $1.5 \mathrm{ml}$ eppendoff tubes, frozen in liquid nitrogen and transported to the biotechnology laboratory for DNA extraction. The liquid nitrogen preservation was to keep the samples fresh and prevents the DNA from degradation.

\subsection{Genomic DNA Isolation}

The genomic DNA extraction was done at the Crops Research Institute (CRI), Fumesua-Kumasi, Ghana, of the Council for Scientific and Industrial Research using the modified DNA isolation method [20] and adopted by the CRI. The DNA extraction buffer contained $1 \mathrm{M}$ of Tris- $\mathrm{HCl}(\mathrm{pH}$ $8.0), 5 \mathrm{M} \mathrm{NaCl}, 0.5 \mathrm{M}$ EDTA (pH 8.0), (10000mwt) poly vinyl pirrolidone, $20 \%$ sarkosine, sodium metabisuphite, $10 \%$ sodium ascorbate. $200 \mathrm{mg}$ of leaf tissue was weighed into $2 \mathrm{ml}$ eppendorf tube and ground to fine powder with liquid nitrogen and $800 \mu \mathrm{l}$ of lysis buffer was used to lyses the nuclear membrane. The lysis buffer contained $1 \mathrm{M}$ of Tris- $\mathrm{HCl}(\mathrm{pH}$ 8.0), $5 \mathrm{M} \mathrm{NaCl}, 0.5 \mathrm{M}$ EDTA (pH 8.0), (10000mwt) poly vinyl pirrolidone, $20 \%$ sarkosine, sodium metabisuphite, $10 \%$ sodium ascorbate. The protein contaminates were removed using $400 \mu \mathrm{l}$ of $5 \mathrm{M}$ potassium acetate ([20] used $800 \mu \mathrm{l}$ of phenol chloroform isoamyl alcohol) and entrifugation at $1300 \mathrm{rpm}$ for 15 minutes. The DNA was precipitated and centrifuged at $13000 \mathrm{rpm}$ for 10 minutes. The RNA component was also removed by adding $4 \mu \mathrm{l}$ RNase $\mathrm{A}$ and incubated at $37^{\circ} \mathrm{C}$. DNA purification and recovery was carried out using $700 \mu$ isopropanol and $80 \%$ alcohol. DNA pellets were then dried at room temperature and dissolved in $200 \mu$ of 1 X TBE buffer. DNA quality and quantity were determined on $0.8 \%$ agarose gel using a $100 \mathrm{bp}$ standard DNA ladder as a reference.

\subsection{RAPD and ISSR Amplification and Detection of PCR Products}

A total number of 45 RAPD and 10 ISSR primers (Invitrogen, UK) were screened using randomly selected DNA samples. From the preliminary screening, 5 of the RAPD and 5 of the ISSR primers were highly reproducible and amplified with distinct and visible bands. These were selected for further examination of all the $C$. pentandra DNA samples. In performing the PCR, premix for genomic DNA was prepared using $1 \mathrm{ul}$ of $10 \mathrm{x}$ buffer, $0.2 \mathrm{Ll}$ Taq polymerase (Industricod, South Africa), 0.91 ц $25 \mathrm{mM} \mathrm{MgCl}_{2}, 0.4 ц \mathrm{l}$ $10 \mathrm{mM}$ dNTPs, $0.5 ц l$ of each primer, $6 ц l$ nuclease free water, 1цl DNA (10ng/цl) which added up to a total reaction volume of 10 цl. 10 цl of nuclease free water was used as a control. The thermal cycler, (GenAmp PCR System 9700, version 3.09, Applied Biosystems), was programmed for 30 cycles and was run 2 hours, 27 minutes and 2 seconds. Initial denaturation was 3 minutes at $94^{\circ} \mathrm{C}$, followed by 30 cycles of 1 minute at $94^{\circ} \mathrm{C}, 1$ minute at $48^{\circ} \mathrm{C}, 1$ minute at $72^{\circ} \mathrm{C}$ and 7 minutes final extension step at $72^{\circ} \mathrm{C}$. The hold temperature 
was set at $4^{\circ} \mathrm{C}$. The amplified PCR products were analyzed using the principle of electrophoresis on $2 \%$ agarose gels stained with ethidium bromide in a horizontal gel casting tray (BioRad, UK Ltd). DNA samples from all the 36 accessions were loaded in separate lanes on the gel and repeated for all the 5 RAPD and 5 ISSR reproducible primers. Differences between accessions were detected based on the relative movement of their DNA fragments in the electric field provided by the process. The rate of DNA migration is dependent on their fragment size. Hence, variability among accessions was determined by the positions of their respective DNA fragments on the gel in comparison with standard 100bp DNA size maker. Amplified DNA loci were manually scored as present (1) or absent (0) for each primer and a bi-variate 1-0 data matrix generated. Every scorable band was considered as a single locus/allele. Variations in band presence were recorded as polymorphisms.

\subsection{Data Analysis}

The similarity and dissimilarity matrices were computed using GenStat Discovery (Edition 3) using the Euclidean test option. The RAPD and ISSR polymorphism were analyzed separately. Data from the two techniques were also combined and analyzed. Combining RAPD and ISSR data allows a larger portion of the genome to be sampled resulting in more robust conclusion than the individual techniques [11]. Dendrograms using Unweighted Pair Group of Arithmetic Means (UPGMA) accessions based on Nei's standard genetic distances [21] generated by GenStat Discovery (Edition 3). The strength of the dendrograms nodes were estimated with a bootstrap analysis using 10000 permutations. This was done to enable the global genetic relationships among accessions to be observed. Principal coordinate analysis (PCoA) was done with this same analytical tool. Pair-wise genetic distances were calculated using UPGMA procedure [22] with GenStat Discovery (Edition 3) as $\mathrm{GD}=1-\mathrm{d} x \mathrm{~d} / \mathrm{dx}+\mathrm{dy}-\mathrm{dxy}$. Where: GD = Genetic distance between two accessions, dxy $=$ total number of common loci (bands) in two accessions, $\mathrm{dx}$ $=$ total number of loci (bands) in accession 1 and dy $=$ total numbers of loci (bands) in accession 2.

\section{Results}

\subsection{Genetic Diversity as Revealed by RAPD Analysis}

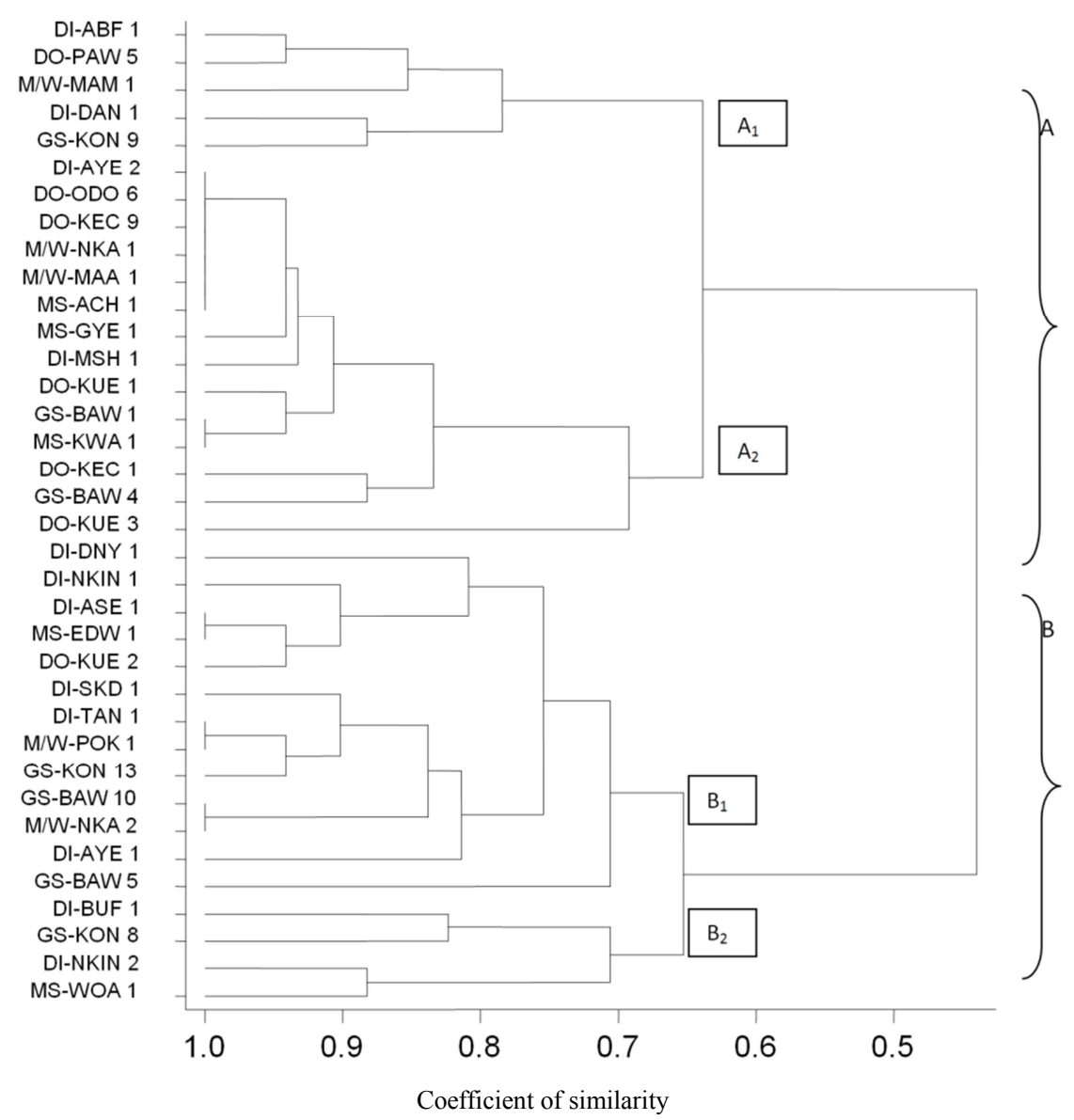

Fig. 1. Dendrogram showing relationships among 36 accessions of C. pentandra based on RAPD polymorphism. See table A1 for similarity matrix used for the construction of the dendrogram.

Key: DI = Dry Semi-deciduous Forest Zone-Inner, DO = Dry Semi-deciduous Forest Zone- Outlier, MS = Moist Semi-deciduous Forest Zone, M/W = Moist/Wet Evergreen Forest Zone, GSZ = Guinea Savanna Zone. 
Association among the 36 accessions revealed by UPGMA cluster analysis is shown in Figure 1. The accessions were clustered into two major groups, $\mathrm{A}$ and $\mathrm{B}$ at a similarity coefficient of 0.5 . Cluster $A$ had two sub-clusters $\left(A_{1}\right.$ and $\left.A_{2}\right)$ likewise cluster $B\left(B_{1}\right.$ and $\left.B_{2}\right)$ at a similarity coefficient of 0.64 and 0.65 , respectively. All groups contained accessions from the entire range of the species. The genetic similarity revealed among the accessions ranged from 0.06 to 1 (Table A1). Fourteen $(38.89 \%)$ of the accessions, representing all the five ecological zones, had a coefficient of similarity of 1 (Fig. 1). The most diverged accessions were BAW 1 and KON 8 with $94 \%$ dissimilarity. This was followed by $88 \%$ dissimilarity between accessions NKA 1 and KON 8, ACH 1 and KON 8, MAA 1 and KON 8, KEC 1 and BAW 5, and between BAW 4 and BAW 5 (Tables A1). Two accessions,
KUE 3 and BAW 5, were unique among the 36 screened.

\subsection{Genetic Diversity as Revealed by ISSR Analysis}

Figure 2 shows the association among accessions based on UPGMA cluster analysis of ISSR polymorphism. The dendrogram contained two major clusters, $\mathrm{C}$ and D. Cluster $\mathrm{C}$ contained four subclusters $\left(\mathrm{C}_{1}-\mathrm{C}_{4}\right)$. The similarity coefficient ranged from 1 to 0.21 (Tables A2) with 21 $(58.33 \%)$ of the accessions having a coefficient of similarity of 1 . These accessions are duplicates and only one could be selected at a time. Accessions BAW 10 and ASE 1 were the most unrelated among the 36 with about $79 \%$ dissimilarity between them.

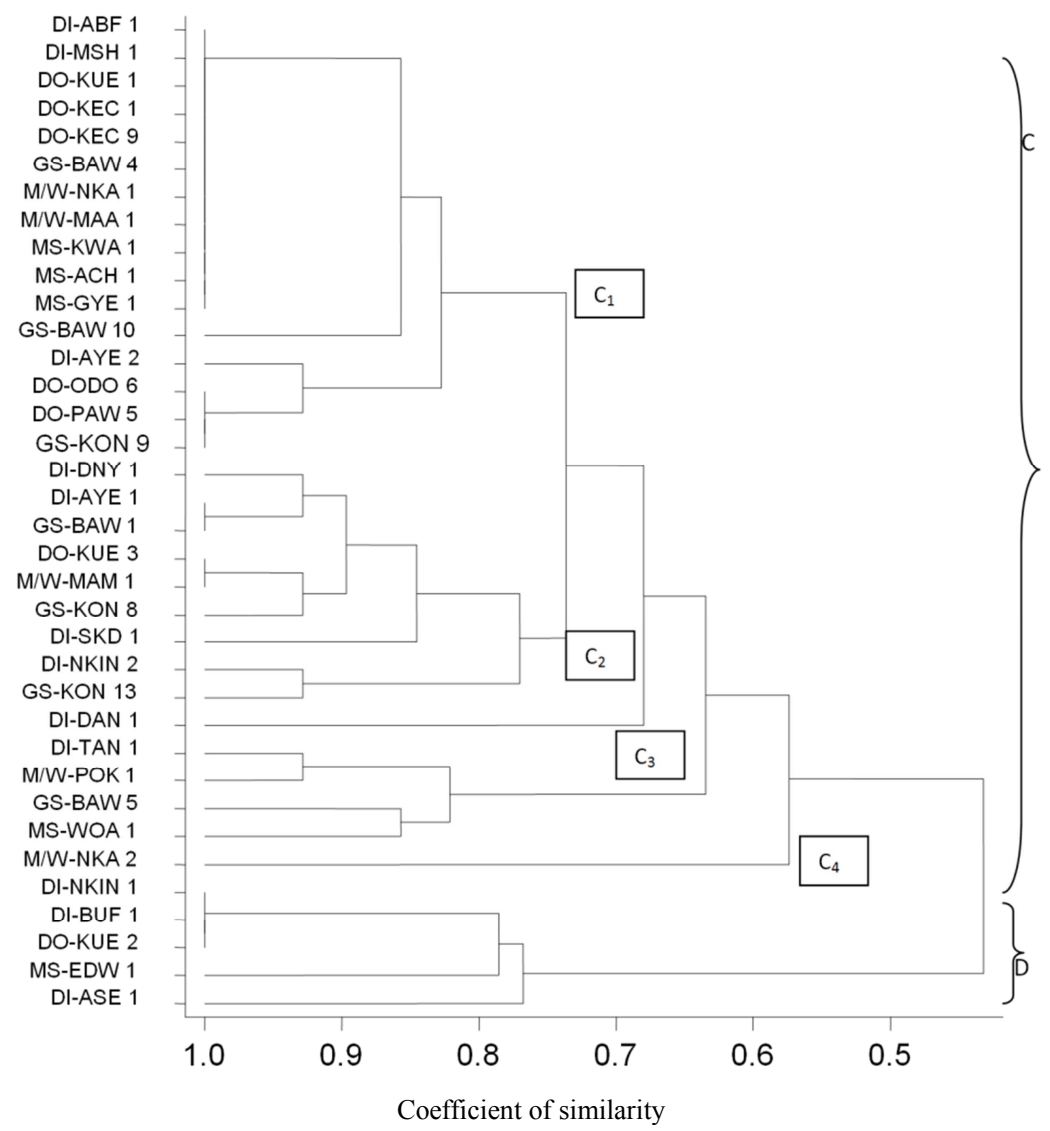

Fig. 2. Dendrogram showing the genetic relationships among 36 accessions of C. pentandra based on ISSR olymorphism. See table A2 for similarity matrix used for the construction of the dendrogram.

Key: DI = Dry Semi-deciduous Forest Inner Zone, DO = Dry Semi-deciduous Forest Zone- Outlier, MSFZ = Moist Semi-deciduous Forest Zone, M/W = Moist/Wet Evergreen Forest Zone, GSZ = Guinea Savanna Zone

\subsection{Genetic Diversity as Revealed by the Combined RAPD and ISSR Analysis}

The dendrogram showed two clusters at a coefficient of similarity of 0.6 : the more diverse group $\mathrm{E}$ and the less diverse Group F (Fig. 3). Cluster E had two sub-clusters, $E_{1}$ and $E_{2}$, at a similarity coefficient of 0.62 . Similarity coefficient ranged from 1 to 0.23 with 4 (11.11\%) of the accessions having a similarity coefficient of 1 and are duplicates. Accessions BUF 1 and KUE 1 had the highest degree of dissimilarity of $77 \%$. Four accessions, BAW 1, KUE 3, DAN 1 and BAW 5, were very unique among the 36. Like the results from the RAPD and ISSR analysis, variation among accessions as revealed by the combined data of RAPD and ISSR was neither population- structured nor followed any known pattern. The principal component analysis (PcoA) defined by axis 1 and 2 accounted for $67.15 \%$ of the variation observed (Fig. 4 ). 


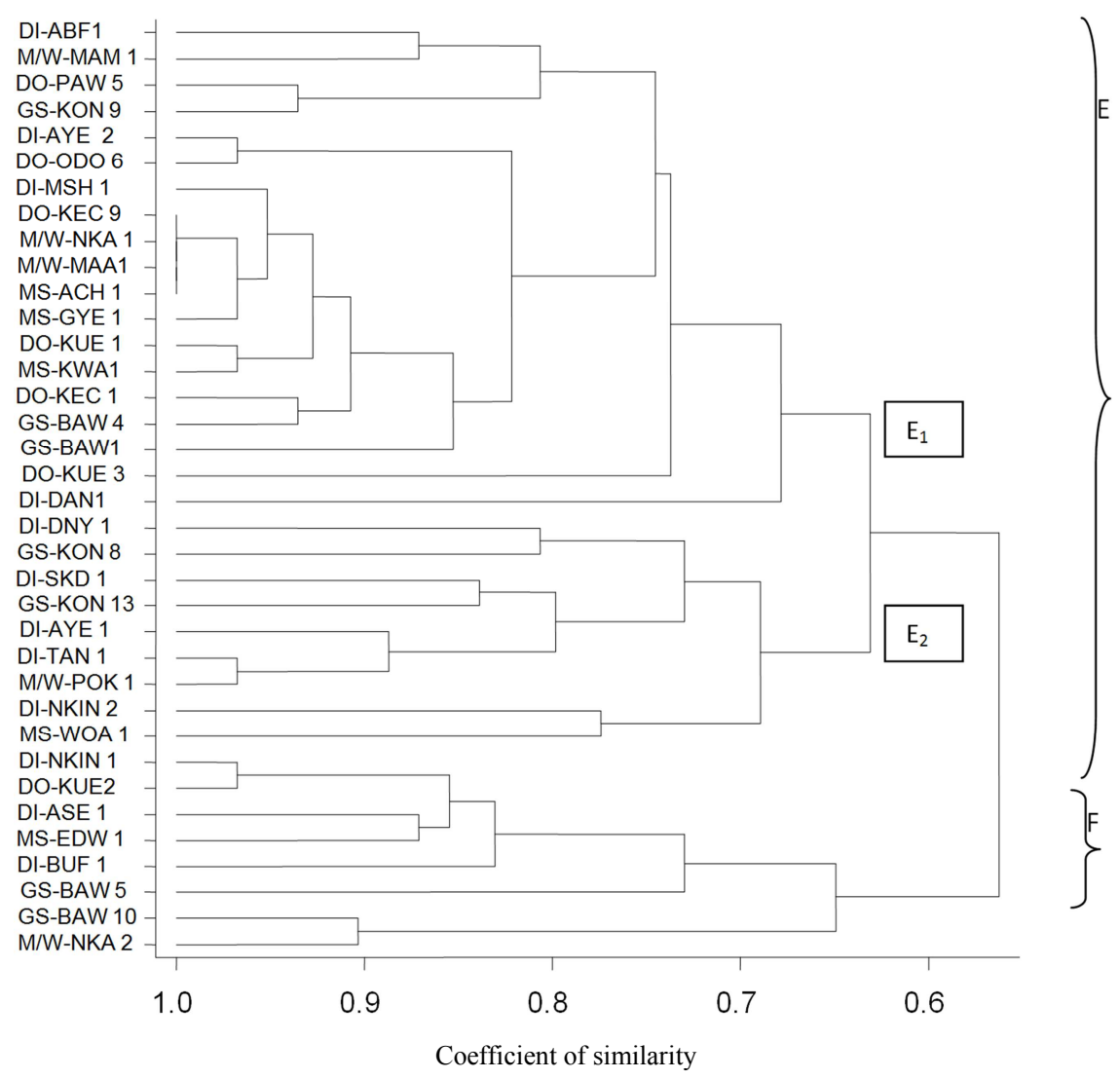

Fig. 3. Dendrogram showing relationships among 36 accessions of C. pentandra base on RAPD and ISSR polymorphism.

Key: DI $=$ Dry Semi-deciduous Forest Inner Zone, DO $=$ Dry Semi-deciduous Forest Zone- Outlier, MSFZ $=$ Moist Semi-deciduous Forest Zone, M/W $=$ Moist/Wet Evergreen Forest Zone, GSZ = Guinea Savanna Zone

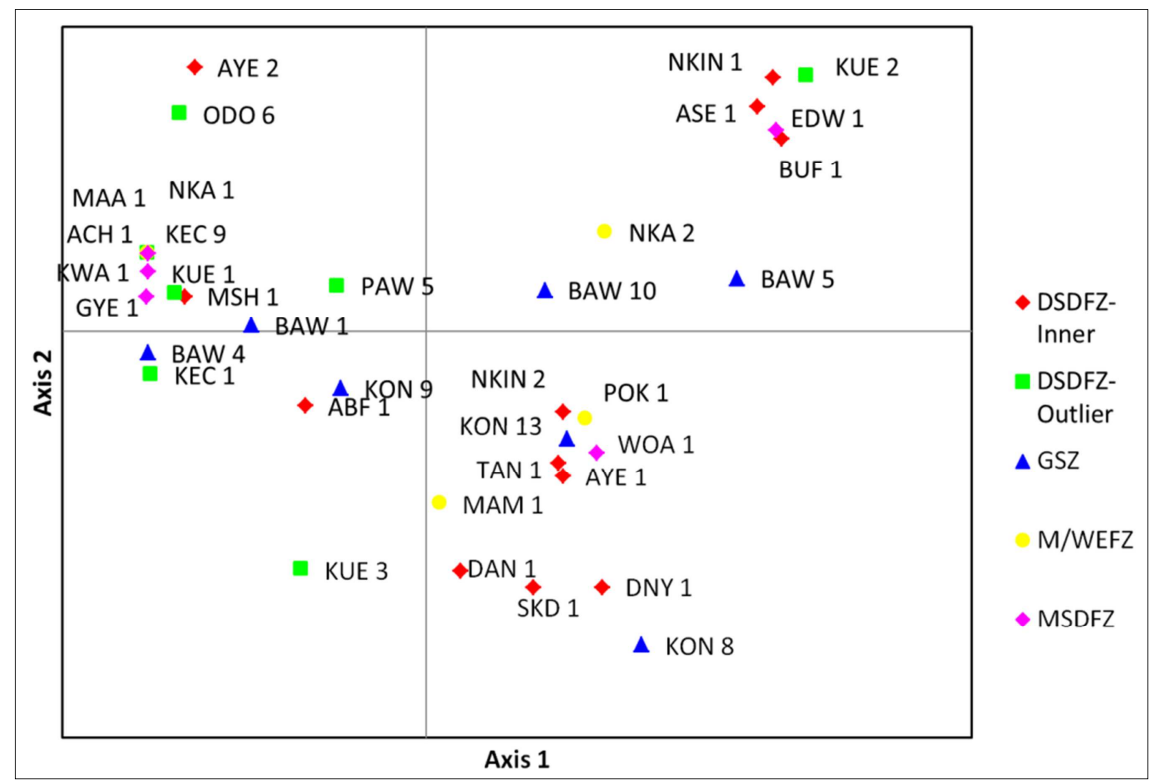

Fig. 4. Principal Coordinate analysis of 36 accessions of C. pentandra from five populations based on RAPD and ISSR polymorphism.

Key

ABF 1 (Abofour), ASE 1 (Asieso-Via Offinso), AYE $1 \& 2$ (Ayerede), BUF 1 (Buabeng-Fiema), DNY 1 (Dua Yaw Nkwanta), MSH 1 (Mampong Scrap Hills), NKIN 1, 2 (Nkinkaso), SKD 1 (Sunyani Koforidua), TAN 1 (Tanaso), KUE 1, 2, 3 (Kue), ODO 6 (Odomi), PAW 5 (Pawa), BAW 1, 4, 5, 10 (Bawku), KEC 1, 9 (Kecheibi), KON 8, 9, 13 (Kongo), MAA 1 (Mankesim), MAM 1 (Manso-Amenfi), NKA 1, 2 (Nkafoa), POK 1 (Pokuase), DAN 1 (Danaso), ACH 1 (Achianse), EDW 1 (Edwinase), GYE 1 (Gyedam), KWA 1 (Kwaso), WOA 1 (Woarakese).

Note: Accessions names are outside the brackets. Names inside the brackets are localities in Ghana where the accessions were collected. 


\section{Discussion}

First, clusters in all the dendrograms contained accessions from different ecological zones. Thus, accessions were not structured by populations or any known pattern. The RAPD markers showed 14 accessions (38.89\%) are genetically similar (Fig. 1). The ISSR markers gave the highest number of accessions, $21(58.33 \%)$, with similarity coefficient of 1 (Fig. 2). The combined RAPD and ISSR makers gave the least with only four accessions (11.11\%) having a similarity coefficient of 1 out of the 36 accessions studied (Fig. 3). The most distantly related accessions were BAW 1 and KON 8 with $94 \%$ dissimilarity as revealed by the RAPD fragments (Table A1). This was followed by $79 \%$ dissimilarity between BAW 10 and ASE 1 from the ISSR analysis (Tables A2). The combined RAPD and ISSR, on the other hand, revealed BUF 1 and KUE 1 to be the least similar with $77 \%$ dissimilarity.

The three dendrographs present several ways in which selection of genetically unrelated accessions could be made. Accessions with coefficient of similarity of one are duplicates and only one should be preferred at a time. For instance, the accessions AYE 2, ODO 6, KEC 9, NKA 1, MAA 1, ACH 1, BAW 1, KWA 1, ASE 1, EDW 1, TAN 1, POK 1, BAW 10 and NKA 2, are all duplicates based on the RAPD polymorphism and only one should be taken (Fig. 1). Likewise, the 21 accessions, ABF 1, MSH 1, KUE 1, KEC 1, KEC 9, BAW 4, NKA 1, MAA1, KWA 1, ACH 1, GYE 1, ODO 6, PAW 5, KON 9, AYE 1, BAW 1, KUE 3, MAM 1, NKIN 1, BUF 1, and KUE 2 are duplicates, based on the ISSR polymorphism (Fig. 2). Again, the four accessions, KEC 9, NKA 1, MAA1 and ACH 1 are duplicates, based on the combined RAPD and ISSR polymorphism (Fig. 3). All the three techniques, RAPD, ISSR and the combined RAPD and ISSR show that two accessions; DNY 1 and SKD 1 were truly unrelated. It was therefore suggested that much priority be given to these accessions in the conservation programme of $C$. pentandra. The PCA which accounted for $67.17 \%$ of the total variation in axis 1 and axis 2 showed some uniqueness in 13 accessions (36.11\%). These included AYE 2, ODO 6, PAW5 and BAW 1 (first quadrant; top left on PCA chart), NKA 2, BAW 10 and BAW 5 (second quadrant; top right on PCA chart), DAN 1, MAM 1, DNY 1, KON 8 and SKD 1 (third quadrant; bottom right on PCA chart) and KUE 3 (forth quadrant; bottom left on PCA chart) as shown in Figure 4.

Three of these accessions, KON 8, BUF 1 and KUE 1, from the three dendrograms and seven from the PCA: KON8, ODO 6, MAM 1, DNY 1, SKD 1, NKA 2 and DAN 1, were previously identified to have the potential of giving a future gain when selected [23]. This means only nine accessions $(25 \%)$ out of the 36 tested were useful in the sustainable management of $C$. pentandra. This number is woefully inadequate and calls for the need for further studies in this subject matter to ensure the identification and maintenance of broad genetic base among the remnant populations of $C$. pentandra. The number of genetically related accessions, $38.89 \%$ (RAPD), $58.33 \%$ (ISSR) and $11.11 \%$ (combined
RAPD and ISSR), suggests possible genetic erosion in the species and calls for gene conservation methods to put in place, timely. It is also an indication that self-pollination in C. pentandra may be higher than that of cross-pollination and hence increasing the chances of inbreeding depression. Thus, the current rate of extraction of this species may be unfavourable to pollinator movement resulting in reduced inter-tree pollination efficiency and out-crossing rates. The adverse effects of inbreeding depression are many including increased fecundity, embryo abortion, limited fruit set, reduced seed yield, lower germination rates, lower seedling vigour and poor growth form leading to poor productivity at maturity [24, 25]. Inbreeding depression can cause population and/or species extinction [26, 27]. Evolutionary forces such as genetic drift and natural selection pressure have been reported to be the main factor accounting for the variability observed in 20 accessions of Monodora myristica in South Eastern Nigeria [28]. The low genetic variation among accessions has serious implications on the management of the genetic resources of $C$. pentandra. It is an indication that the current methods of germplasm exchange and management of the species have high risk on its sustainable utilization and conservation. Hence, the current practice of collecting seed from the wild with unknown genetic quality for use in plantations under the National Forest Plantation Development Programme should be reviewed. It is also suggested that all the plantations that have been established with unscreened planting stock need to be screened and individuals of poor genetic integrity uprooted. Furthermore, genetic screening should be extensively conducted in all the ecological zones of Ghana for more trees of high genetic quality to be identified and preserved as seed trees. Again, genetic diversity is the first basic step in breeding

\section{Conclusion}

C. pentandra is a fast growing-pioneer species and can grow in all the forest zones of Ghana including those with low soil fertility. This makes it a potentially important species for forest regeneration and timber production on disturbed lands. It is particularly successful at colonizing highly disturbed areas. C. pentandra in Ghana constitutes a rich source of biodiversity and conservation and utilization requires a good knowledge on its genetic diversity and characterization. This could assist in the understanding of its evolutionary history and response to environmental changes as well as the mechanisms of its local spread and adaptation. The study showed that genetic diversity in $C$. pentandra is dependent on the degree of germplasm exchange. It is therefore advisable that sampling for conservation and plantation establishment be concentrated on selecting unrelated accessions from the entire range of the species. However, the few accessions identified in the study to have good genetic diversity, is a concern to the sustainability of the species. There is therefore the need to further study, 
identify and preserve a broad genetic diversity in $C$. pentandra. The findings of this study are therefore recommendable to all stakeholders in the forestry industry especially those using $C$. pentandra as a major species in their plantation development projects.

\section{Acknowledgment}

We are very grateful to the International Foundation for Science (IFS), the Kwame Nkrumah University of Science and Technology (KNUST) and the Tropenbos InternationalGhana for providing financial support to this work. We acknowledge Mrs Theresa Peprah of the Forestry Research Institute of Ghana for all the support she provided to make this work a success. We also thank the technicians of the Molecular Laboratories of both the Forestry Research Institute of Ghana (FORIG) and the Crops Research Institute, all of the Council for Scientific and Industrial Research (CSIR), for their co-operation and assistance.

\section{Appendix}

Table A1. Matrix of genetic distances obtained from the RAPD data and used to generate the dendrogram shown in Fig. 1.

\begin{tabular}{|c|c|c|c|c|c|c|c|c|c|c|c|c|c|c|c|c|c|c|}
\hline & $\frac{\sqrt{2}}{\frac{1}{2}}$ & 文 & $\frac{\bar{Z}}{\bar{a}}$ & 玄 & $\begin{array}{l}\overline{5} \\
\frac{0}{\overline{1}}\end{array}$ & 矛 & $\begin{array}{l}\overline{\hat{\theta}} \\
\overline{1} \\
\overline{1} \\
\overline{\hat{\theta}}\end{array}$ & $\underset{\frac{1}{2}}{\overrightarrow{1}}$ & $\begin{array}{l}\text { N } \\
\frac{1}{2} \\
\frac{1}{2}\end{array}$ & $\begin{array}{l}\mathbf{Z} \\
\frac{Z}{Z} \\
\frac{1}{2}\end{array}$ & $\frac{\bar{z}}{\bar{z}}$ & $\sum_{\frac{\pi}{1}}^{\overline{0}}$ & $\begin{array}{l}N \\
\text { 됭 } \\
\frac{1}{1} \\
0\end{array}$ & 喪 & $\begin{array}{l}0 \\
0 \\
0 \\
0 \\
1 \\
0\end{array}$ & $\begin{array}{l}m \\
\frac{1}{5} \\
\frac{1}{b}\end{array}$ & 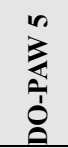 & 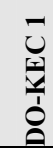 \\
\hline DI-ABF 1 & 1 & & & & & & & & & & & & & & & & & \\
\hline DI-DNY 1 & 0.65 & 1 & & & & & & & & & & & & & & & & \\
\hline DI-DAN 1 & 0.71 & 0.71 & 1 & & & & & & & & & & & & & & & \\
\hline DI-NKIN 1 & 0.59 & 0.82 & 0.65 & 1 & & & & & & & & & & & & & & \\
\hline DI-BUF 1 & 0.53 & 0.76 & 0.59 & 0.71 & 1 & & & & & & & & & & & & & \\
\hline DI-ASE 1 & 0.59 & 0.82 & 0.53 & 0.88 & 0.82 & 1 & & & & & & & & & & & & \\
\hline DI-SKD 1 & 0.65 & 0.76 & 0.71 & 0.71 & 0.65 & 0.71 & 1 & & & & & & & & & & & \\
\hline DI-AYE 1 & 0.76 & 0.76 & 0.59 & 0.71 & 0.76 & 0.82 & 0.76 & 1 & & & & & & & & & & \\
\hline DI-AYE 2 & 0.76 & 0.41 & 0.47 & 0.35 & 0.29 & 0.35 & 0.41 & 0.53 & 1 & & & & & & & & & \\
\hline DI-NKIN 2 & 0.65 & 0.76 & 0.59 & 0.71 & 0.76 & 0.71 & 0.53 & 0.76 & 0.41 & 1 & & & & & & & & \\
\hline DI-TAN 1 & 0.76 & 0.65 & 0.59 & 0.71 & 0.65 & 0.71 & 0.88 & 0.88 & 0.53 & 0.65 & 1 & & & & & & & \\
\hline DI-MSH 1 & 0.82 & 0.47 & 0.53 & 0.41 & 0.35 & 0.41 & 0.47 & 0.59 & 0.94 & 0.47 & 0.59 & 1 & & & & & & \\
\hline DO-KUE 2 & 0.53 & 0.76 & 0.59 & 0.94 & 0.76 & 0.94 & 0.76 & 0.76 & 0.29 & 0.65 & 0.76 & 0.35 & 1 & & & & & \\
\hline DO-KUE 1 & 0.65 & 0.41 & 0.59 & 0.47 & 0.18 & 0.35 & 0.53 & 0.41 & 0.88 & 0.29 & 0.53 & 0.82 & 0.41 & 1 & & & & \\
\hline DO-ODO 6 & 0.76 & 0.41 & 0.47 & 0.35 & 0.29 & 0.35 & 0.41 & 0.53 & 1 & 0.41 & 0.53 & 0.94 & 0.29 & 0.88 & 1 & & & \\
\hline DO-KUE 3 & 0.65 & 0.41 & 0.71 & 0.35 & 0.41 & 0.24 & 0.53 & 0.41 & 0.65 & 0.53 & 0.53 & 0.71 & 0.29 & 0.65 & 0.65 & 1 & & \\
\hline DO-PAW 5 & 0.94 & 0.59 & 0.76 & 0.65 & 0.47 & 0.53 & 0.71 & 0.71 & 0.71 & 0.59 & 0.82 & 0.76 & 0.59 & 0.71 & 0.71 & 0.71 & 1 & \\
\hline DO-KEC 1 & 0.59 & 0.35 & 0.65 & 0.29 & 0.35 & 0.18 & 0.47 & 0.35 & 0.82 & 0.35 & 0.47 & 0.76 & 0.24 & 0.82 & 0.82 & 0.82 & 0.65 & 1 \\
\hline DO-KEC 9 & 0.76 & 0.41 & 0.47 & 0.35 & 0.29 & 0.35 & 0.41 & 0.53 & 1 & 0.41 & 0.53 & 0.94 & 0.29 & 0.88 & 1 & 0.65 & 0.71 & 0.82 \\
\hline GS-BAW 4 & 0.59 & 0.24 & 0.53 & 0.29 & 0.24 & 0.18 & 0.35 & 0.35 & 0.82 & 0.47 & 0.47 & 0.76 & 0.24 & 0.82 & 0.82 & 0.82 & 0.65 & 0.88 \\
\hline GS-KON 13 & 0.71 & 0.71 & 0.65 & 0.76 & 0.59 & 0.76 & 0.94 & 0.82 & 0.47 & 0.59 & 0.94 & 0.53 & 0.82 & 0.59 & 0.47 & 0.47 & 0.76 & 0.41 \\
\hline GS-BAW 5 & 0.53 & 0.65 & 0.47 & 0.71 & 0.65 & 0.82 & 0.65 & 0.76 & 0.29 & 0.53 & 0.65 & 0.35 & 0.76 & 0.29 & 0.29 & 0.18 & 0.47 & 0.12 \\
\hline GS-KON 8 & 0.35 & 0.71 & 0.53 & 0.65 & 0.82 & 0.76 & 0.59 & 0.59 & 0.12 & 0.71 & 0.47 & 0.18 & 0.71 & 0.12 & 0.12 & 0.35 & 0.29 & 0.18 \\
\hline GS-BAW 1 & 0.71 & 0.35 & 0.53 & 0.41 & 0.24 & 0.29 & 0.47 & 0.47 & 0.94 & 0.35 & 0.59 & 0.88 & 0.35 & 0.94 & 0.94 & 0.71 & 0.76 & 0.88 \\
\hline GS-BAW 10 & 0.65 & 0.65 & 0.47 & 0.82 & 0.76 & 0.82 & 0.76 & 0.76 & 0.41 & 0.65 & 0.88 & 0.47 & 0.88 & 0.41 & 0.41 & 0.41 & 0.71 & 0.35 \\
\hline GS-KON 9 & 0.82 & 0.59 & 0.88 & 0.53 & 0.59 & 0.41 & 0.71 & 0.59 & 0.59 & 0.59 & 0.71 & 0.65 & 0.47 & 0.59 & 0.59 & 0.82 & 0.88 & 0.76 \\
\hline M/W-MAM 1 & 0.88 & 0.76 & 0.82 & 0.71 & 0.53 & 0.71 & 0.65 & 0.76 & 0.65 & 0.65 & 0.65 & 0.71 & 0.65 & 0.65 & 0.65 & 0.53 & 0.82 & 0.47 \\
\hline M/W-NKA 1 & 0.76 & 0.41 & 0.47 & 0.35 & 0.29 & 0.35 & 0.41 & 0.53 & 1 & 0.41 & 0.53 & 0.94 & 0.29 & 0.88 & 1 & 0.65 & 0.71 & 0.82 \\
\hline M/W-MAA 1 & 0.76 & 0.41 & 0.47 & 0.35 & 0.29 & 0.35 & 0.41 & 0.53 & 1 & 0.41 & 0.53 & 0.94 & 0.29 & 0.88 & 1 & 0.65 & 0.71 & 0.82 \\
\hline M/W-NKA 2 & 0.65 & 0.65 & 0.47 & 0.82 & 0.76 & 0.82 & 0.76 & 0.76 & 0.41 & 0.65 & 0.88 & 0.47 & 0.88 & 0.41 & 0.41 & 0.41 & 0.71 & 0.35 \\
\hline M/W-POK 1 & 0.76 & 0.65 & 0.59 & 0.71 & 0.65 & 0.71 & 0.88 & 0.88 & 0.53 & 0.65 & 1 & 0.59 & 0.76 & 0.53 & 0.53 & 0.53 & 0.82 & 0.47 \\
\hline MS-EDW 1 & 0.59 & 0.82 & 0.53 & 0.88 & 0.82 & 1 & 0.71 & 0.82 & 0.35 & 0.71 & 0.71 & 0.41 & 0.94 & 0.35 & 0.35 & 0.24 & 0.53 & 0.18 \\
\hline MS-KWA 1 & 0.71 & 0.35 & 0.53 & 0.41 & 0.24 & 0.29 & 0.47 & 0.47 & 0.94 & 0.35 & 0.59 & 0.88 & 0.35 & 0.94 & 0.94 & 0.71 & 0.76 & 0.88 \\
\hline MS-ACH 1 & 0.76 & 0.41 & 0.47 & 0.35 & 0.29 & 0.35 & 0.41 & 0.53 & 1 & 0.41 & 0.53 & 0.94 & 0.29 & 0.88 & 1 & 0.65 & 0.71 & 0.82 \\
\hline MS-WOA 1 & 0.65 & 0.76 & 0.71 & 0.71 & 0.65 & 0.71 & 0.53 & 0.65 & 0.41 & 0.88 & 0.53 & 0.47 & 0.65 & 0.41 & 0.41 & 0.53 & 0.59 & 0.35 \\
\hline MS-GYE 1 & 0.71 & 0.35 & 0.53 & 0.29 & 0.35 & 0.29 & 0.35 & 0.47 & 0.94 & 0.47 & 0.47 & 0.88 & 0.24 & 0.82 & 0.94 & 0.71 & 0.65 & 0.88 \\
\hline
\end{tabular}


Table A1. Continued. Matrix of genetic distances obtained from the ISSR data and used to generate the dendrogram shown in Fig. 1.

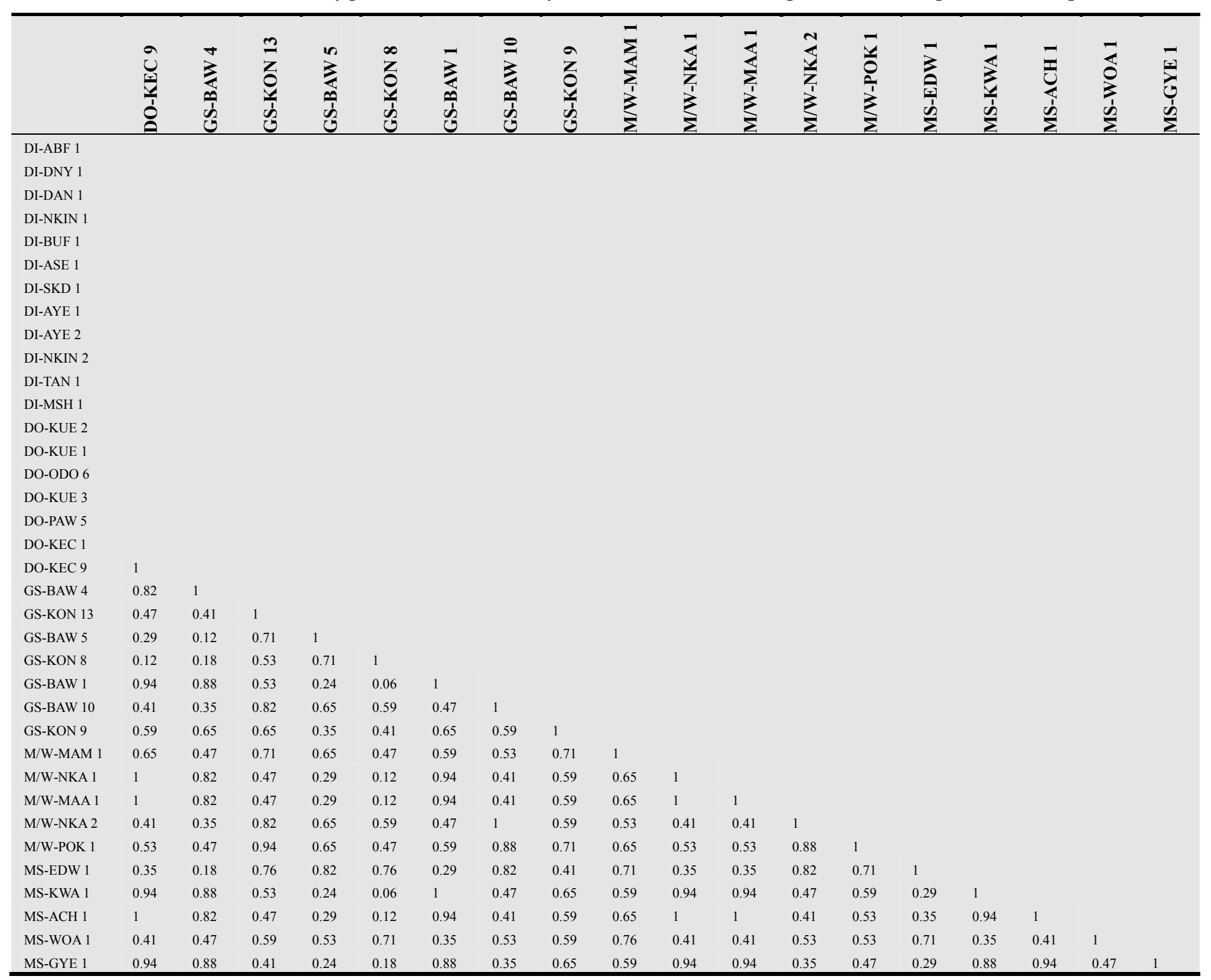

Table A2. Matrix of genetic distances obtained from the ISSR data and used to generate the dendrogram shown in Fig. 2.

\begin{tabular}{|c|c|c|c|c|c|c|c|c|c|c|c|c|c|c|c|c|c|c|}
\hline & 芴 & 育 & $\begin{array}{l}\bar{z} \\
\bar{a} \\
\overline{\mathbf{a}}\end{array}$ & $\overrightarrow{\bar{z}}$ & $\begin{array}{l}\overline{5} \\
\frac{0}{1} \\
\frac{1}{0}\end{array}$ & 离 & $\begin{array}{l}\overrightarrow{\hat{\theta}} \\
\bar{a} \\
\hat{1} \\
\hat{0}\end{array}$ & 至 & 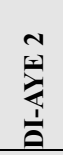 & 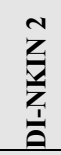 & 玄 & $\sum_{\overline{1}}^{\bar{n}}$ & 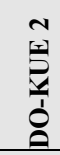 & 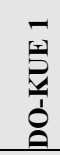 & $\begin{array}{l}0 \\
0 \\
\hat{0} \\
1 \\
0\end{array}$ & 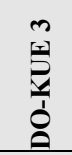 & 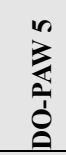 & 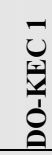 \\
\hline DI-ABF 1 & 1 & & & & & & & & & & & & & & & & & \\
\hline DI-DNY 1 & 0.71 & 1 & & & & & & & & & & & & & & & & \\
\hline DI-DAN 1 & 0.71 & 0.71 & 1 & & & & & & & & & & & & & & & \\
\hline DI-NKIN 1 & 0.29 & 0.43 & 0.43 & 1 & & & & & & & & & & & & & & \\
\hline DI-BUF 1 & 0.29 & 0.43 & 0.43 & 1 & 1 & & & & & & & & & & & & & \\
\hline DI-ASE 1 & 0.36 & 0.5 & 0.36 & 0.79 & 0.79 & 1 & & & & & & & & & & & & \\
\hline DI-SKD 1 & 0.79 & 0.93 & 0.64 & 0.36 & 0.36 & 0.43 & 1 & & & & & & & & & & & \\
\hline DI-AYE 1 & 0.79 & 0.93 & 0.64 & 0.5 & 0.5 & 0.57 & 0.86 & 1 & & & & & & & & & & \\
\hline DI-AYE 2 & 0.79 & 0.5 & 0.64 & 0.5 & 0.5 & 0.57 & 0.57 & 0.57 & 1 & & & & & & & & & \\
\hline DI-NKIN 2 & 0.71 & 0.71 & 0.57 & 0.57 & 0.57 & 0.64 & 0.64 & 0.79 & 0.79 & 1 & & & & & & & & \\
\hline DI-TAN 1 & 0.71 & 0.86 & 0.71 & 0.57 & 0.57 & 0.5 & 0.79 & 0.93 & 0.5 & 0.71 & 1 & & & & & & & \\
\hline DI-MSH 1 & 1 & 0.71 & 0.71 & 0.29 & 0.29 & 0.36 & 0.79 & 0.79 & 0.79 & 0.71 & 0.71 & 1 & & & & & & \\
\hline DO-KUE 2 & 0.29 & 0.43 & 0.43 & 1 & 1 & 0.79 & 0.36 & 0.5 & 0.5 & 0.57 & 0.57 & 0.29 & 1 & & & & & \\
\hline DO-KUE 1 & 1 & 0.71 & 0.71 & 0.29 & 0.29 & 0.36 & 0.79 & 0.79 & 0.79 & 0.71 & 0.71 & 1 & 0.29 & 1 & & & & \\
\hline DO-ODO 6 & 0.86 & 0.57 & 0.57 & 0.43 & 0.43 & 0.5 & 0.64 & 0.64 & 0.93 & 0.86 & 0.57 & 0.86 & 0.43 & 0.86 & 1 & & & \\
\hline DO-KUE 3 & 0.86 & 0.86 & 0.71 & 0.43 & 0.43 & 0.5 & 0.79 & 0.93 & 0.64 & 0.86 & 0.86 & 0.86 & 0.43 & 0.86 & 0.71 & 1 & & \\
\hline DO-PAW 5 & 0.86 & 0.57 & 0.57 & 0.43 & 0.43 & 0.5 & 0.64 & 0.64 & 0.93 & 0.86 & 0.57 & 0.86 & 0.43 & 0.86 & 1 & 0.71 & 1 & \\
\hline DO-KEC 1 & 1 & 0.71 & 0.71 & 0.29 & 0.29 & 0.36 & 0.79 & 0.79 & 0.79 & 0.71 & 0.71 & 1 & 0.29 & 1 & 0.86 & 0.86 & 0.86 & 1 \\
\hline
\end{tabular}




\begin{tabular}{|c|c|c|c|c|c|c|c|c|c|c|c|c|c|c|c|c|c|c|}
\hline & $\begin{array}{l}\bar{x} \\
\frac{1}{0} \\
\frac{1}{\theta}\end{array}$ & 育 & $\begin{array}{l}\bar{z} \\
\bar{a} \\
\overline{\mathbf{a}}\end{array}$ & $\begin{array}{l}\bar{z} \\
\bar{z} \\
\bar{z} \\
\underline{\mathbf{z}}\end{array}$ & $\overrightarrow{5}$ & $\begin{array}{l}-\sqrt{1} \\
\frac{1}{2} \\
\frac{1}{2}\end{array}$ & $\begin{array}{l}\overrightarrow{0} \\
\overrightarrow{0} \\
\overrightarrow{1} \\
\overrightarrow{0}\end{array}$ & $\begin{array}{l}-1 \\
\frac{1}{2} \\
\frac{1}{2}\end{array}$ & $\begin{array}{l}N \\
\frac{1}{2} \\
\frac{1}{2}\end{array}$ & $\frac{N}{Z}$ & $\underset{\frac{1}{a}}{\bar{a}}$ & $\sum_{\frac{1}{0}}^{\overline{0}}$ & $\begin{array}{l}\text { N } \\
\text { 됭 } \\
\frac{1}{d} \\
0\end{array}$ & $\frac{7}{8}$ & $\begin{array}{l}0 \\
0 \\
0 \\
0 \\
1 \\
0 \\
0\end{array}$ & $\begin{array}{l}m \\
\frac{1}{b} \\
\frac{1}{b} \\
0\end{array}$ & $\begin{array}{l}n \\
\vdots \\
0 \\
0\end{array}$ & 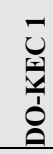 \\
\hline DO-KEC 9 & 1 & 0.71 & 0.71 & 0.29 & 0.29 & 0.36 & 0.79 & 0.79 & 0.79 & 0.71 & 0.71 & 1 & 0.29 & 1 & 0.86 & 0.86 & 0.86 & 1 \\
\hline GS-BAW 4 & 1 & 0.71 & 0.71 & 0.29 & 0.29 & 0.36 & 0.79 & 0.79 & 0.79 & 0.71 & 0.71 & 1 & 0.29 & 1 & 0.86 & 0.86 & 0.86 & 1 \\
\hline GS-KON 13 & 0.64 & 0.79 & 0.64 & 0.5 & 0.5 & 0.57 & 0.71 & 0.71 & 0.71 & 0.93 & 0.64 & 0.64 & 0.5 & 0.64 & 0.79 & 0.79 & 0.79 & 0.64 \\
\hline GS-BAW 5 & 0.5 & 0.64 & 0.5 & 0.79 & 0.79 & 0.57 & 0.57 & 0.71 & 0.29 & 0.5 & 0.79 & 0.5 & 0.79 & 0.5 & 0.36 & 0.64 & 0.36 & 0.5 \\
\hline GS-KON 8 & 0.79 & 0.93 & 0.79 & 0.36 & 0.36 & 0.43 & 0.86 & 0.86 & 0.57 & 0.79 & 0.79 & 0.79 & 0.36 & 0.79 & 0.64 & 0.93 & 0.64 & 0.79 \\
\hline GS-BAW 1 & 0.79 & 0.93 & 0.64 & 0.5 & 0.5 & 0.57 & 0.86 & 1 & 0.57 & 0.79 & 0.93 & 0.79 & 0.5 & 0.79 & 0.64 & 0.93 & 0.64 & 0.79 \\
\hline GS-BAW 10 & 0.86 & 0.57 & 0.71 & 0.43 & 0.43 & 0.21 & 0.64 & 0.64 & 0.64 & 0.57 & 0.71 & 0.86 & 0.43 & 0.86 & 0.71 & 0.71 & 0.71 & 0.86 \\
\hline GS-KON 9 & 0.86 & 0.57 & 0.57 & 0.43 & 0.43 & 0.5 & 0.64 & 0.64 & 0.93 & 0.86 & 0.57 & 0.86 & 0.43 & 0.86 & 1 & 0.71 & 1 & 0.86 \\
\hline M/W-MAM 1 & 0.86 & 0.86 & 0.71 & 0.43 & 0.43 & 0.5 & 0.79 & 0.93 & 0.64 & 0.86 & 0.86 & 0.86 & 0.43 & 0.86 & 0.71 & 1 & 0.71 & 0.86 \\
\hline M/W-NKA 1 & 1 & 0.71 & 0.71 & 0.29 & 0.29 & 0.36 & 0.79 & 0.79 & 0.79 & 0.71 & 0.71 & 1 & 0.29 & 1 & 0.86 & 0.86 & 0.86 & 1 \\
\hline M/W-MAA 1 & 1 & 0.71 & 0.71 & 0.29 & 0.29 & 0.36 & 0.79 & 0.79 & 0.79 & 0.71 & 0.71 & 1 & 0.29 & 1 & 0.86 & 0.86 & 0.86 & 1 \\
\hline M/W-NKA 2 & 0.64 & 0.5 & 0.64 & 0.5 & 0.5 & 0.29 & 0.57 & 0.43 & 0.43 & 0.36 & 0.5 & 0.64 & 0.5 & 0.64 & 0.5 & 0.5 & 0.5 & 0.64 \\
\hline M/W-POK 1 & 0.64 & 0.79 & 0.64 & 0.64 & 0.64 & 0.43 & 0.71 & 0.86 & 0.43 & 0.64 & 0.93 & 0.64 & 0.64 & 0.64 & 0.5 & 0.79 & 0.5 & 0.64 \\
\hline MS-EDW 1 & 0.36 & 0.5 & 0.36 & 0.79 & 0.79 & 0.71 & 0.43 & 0.57 & 0.43 & 0.64 & 0.64 & 0.36 & 0.79 & 0.36 & 0.5 & 0.5 & 0.5 & 0.36 \\
\hline MS-KWA 1 & 1 & 0.71 & 0.71 & 0.29 & 0.29 & 0.36 & 0.79 & 0.79 & 0.79 & 0.71 & 0.71 & 1 & 0.29 & 1 & 0.86 & 0.86 & 0.86 & 1 \\
\hline MS-ACH 1 & 1 & 0.71 & 0.71 & 0.29 & 0.29 & 0.36 & 0.79 & 0.79 & 0.79 & 0.71 & 0.71 & 1 & 0.29 & 1 & 0.86 & 0.86 & 0.86 & 1 \\
\hline MS-WOA 1 & 0.64 & 0.64 & 0.64 & 0.64 & 0.64 & 0.43 & 0.57 & 0.71 & 0.43 & 0.64 & 0.79 & 0.64 & 0.64 & 0.64 & 0.5 & 0.79 & 0.5 & 0.64 \\
\hline MS-GYE 1 & 1 & 0.71 & 0.71 & 0.29 & 0.29 & 0.36 & 0.79 & 0.79 & 0.79 & 0.71 & 0.71 & 1 & 0.29 & 1 & 0.86 & 0.86 & 0.86 & 1 \\
\hline
\end{tabular}

Table A2. Continued. Matrix of genetic distances obtained from the ISSR data and used to generate the dendrogram shown in Fig. 2.

\begin{tabular}{|c|c|c|c|c|c|c|c|c|c|c|c|c|c|c|c|c|c|c|}
\hline & $\begin{array}{l}a \\
\text { Und } \\
\vdots 1 \\
0 \\
0\end{array}$ & 荿 & $\begin{array}{l}m \\
z \\
0 \\
\frac{1}{1} \\
0 \\
0\end{array}$ & 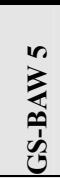 & $\begin{array}{l}\infty \\
z \\
0 \\
1 \\
\vdots \\
0 \\
0\end{array}$ & $\overline{3}$ & 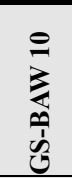 & $\begin{array}{l}a \\
\hat{z} \\
\frac{0}{1} \\
03\end{array}$ & $\sum_{\sum}^{\sum}$ & 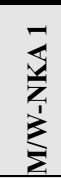 & $\sum_{\sum}^{\overline{1}}$ & 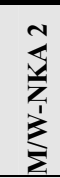 & $\begin{array}{l}\bar{y} \\
\frac{1}{2} \\
\frac{1}{1} \\
\sum\end{array}$ & 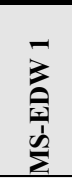 & $\begin{array}{l}\overline{1} \\
\frac{1}{2} \\
\sum^{2} \\
\sum\end{array}$ & 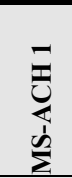 & 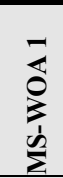 & 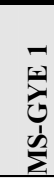 \\
\hline \multicolumn{19}{|l|}{ DI-ABF 1} \\
\hline \multicolumn{19}{|l|}{ DI-DNY 1} \\
\hline \multicolumn{19}{|l|}{ DI-DAN 1} \\
\hline \multicolumn{19}{|l|}{ DI-NKIN 1} \\
\hline \multicolumn{19}{|l|}{ DI-BUF 1} \\
\hline \multicolumn{19}{|l|}{ DI-ASE 1} \\
\hline \multicolumn{19}{|l|}{ DI-SKD 1} \\
\hline \multicolumn{19}{|l|}{ DI-AYE 1} \\
\hline \multicolumn{19}{|l|}{ DI-AYE 2} \\
\hline \multicolumn{19}{|l|}{ DI-NKIN 2} \\
\hline \multicolumn{19}{|l|}{ DI-TAN 1} \\
\hline \multicolumn{19}{|l|}{ DI-MSH 1} \\
\hline \multicolumn{19}{|l|}{ DO-KUE 2} \\
\hline \multicolumn{19}{|l|}{ DO-KUE 1} \\
\hline \multicolumn{19}{|l|}{ DO-ODO 6} \\
\hline \multicolumn{19}{|l|}{ DO-KUE 3} \\
\hline \multicolumn{19}{|l|}{ DO-PAW 5} \\
\hline \multicolumn{19}{|l|}{ DO-KEC 1} \\
\hline DO-KEC 9 & 1 & & & & & & & & & & & & & & & & & \\
\hline GS-BAW 4 & 1 & 1 & & & & & & & & & & & & & & & & \\
\hline GS-KON 13 & 0.64 & 0.64 & 1 & & & & & & & & & & & & & & & \\
\hline GS-BAW 5 & 0.5 & 0.5 & 0.43 & 1 & & & & & & & & & & & & & & \\
\hline GS-KON 8 & 0.79 & 0.79 & 0.86 & 0.57 & 1 & & & & & & & & & & & & & \\
\hline GS-BAW 1 & 0.79 & 0.79 & 0.71 & 0.71 & 0.86 & 1 & & & & & & & & & & & & \\
\hline GS-BAW 10 & 0.86 & 0.86 & 0.5 & 0.64 & 0.64 & 0.64 & 1 & & & & & & & & & & & \\
\hline GS-KON 9 & 0.86 & 0.86 & 0.79 & 0.36 & 0.64 & 0.64 & 0.71 & 1 & & & & & & & & & & \\
\hline M/W-MAM 1 & 0.86 & 0.86 & 0.79 & 0.64 & 0.93 & 0.93 & 0.71 & 0.71 & 1 & & & & & & & & & \\
\hline M/W-NKA 1 & 1 & 1 & 0.64 & 0.5 & 0.79 & 0.79 & 0.86 & 0.86 & 0.86 & 1 & & & & & & & & \\
\hline M/W-MAA 1 & 1 & 1 & 0.64 & 0.5 & 0.79 & 0.79 & 0.86 & 0.86 & 0.86 & 1 & 1 & & & & & & & \\
\hline M/W-NKA 2 & 0.64 & 0.64 & 0.43 & 0.71 & 0.57 & 0.43 & 0.79 & 0.5 & 0.5 & 0.64 & 0.64 & 1 & & & & & & \\
\hline M/W-POK 1 & 0.64 & 0.64 & 0.57 & 0.86 & 0.71 & 0.86 & 0.79 & 0.5 & 0.79 & 0.64 & 0.64 & 0.57 & 1 & & & & & \\
\hline MS-EDW 1 & 0.36 & 0.36 & 0.57 & 0.71 & 0.43 & 0.57 & 0.5 & 0.5 & 0.5 & 0.36 & 0.36 & 0.43 & 0.71 & 1 & & & & \\
\hline MS-KWA 1 & 1 & 1 & 0.64 & 0.5 & 0.79 & 0.79 & 0.86 & 0.86 & 0.86 & 1 & 1 & 0.64 & 0.64 & 0.36 & 1 & & & \\
\hline MS-ACH 1 & 1 & 1 & 0.64 & 0.5 & 0.79 & 0.79 & 0.86 & 0.86 & 0.86 & 1 & 1 & 0.64 & 0.64 & 0.36 & 1 & 1 & & \\
\hline MS-WOA 1 & 0.64 & 0.64 & 0.57 & 0.86 & 0.71 & 0.71 & 0.79 & 0.5 & 0.79 & 0.64 & 0.64 & 0.71 & 0.86 & 0.57 & 0.64 & 0.64 & 1 & \\
\hline MS-GYE 1 & 1 & 1 & 0.64 & 0.5 & 0.79 & 0.79 & 0.86 & 0.86 & 0.86 & 1 & 1 & 0.64 & 0.64 & 0.36 & 1 & 1 & 0.64 & 1 \\
\hline
\end{tabular}




\section{Abbreviations}

$\begin{array}{ll}\text { Item } & \text { Full meaning } \\ \text { df } & \text { Degree of Freedom } \\ \text { DNA } & \text { Deoxyribonucleic Acid } \\ \text { EDTA } & \text { Ethylenediaminetetraacetic Acid } \\ \text { Fig } & \text { Figure } \\ \mathrm{ft} & \text { Feet } \\ \text { ISSRs } & \text { Inter Simple Sequence Repeats } \\ \mathrm{M} & \text { Molar } \\ \mathrm{ng} & \text { Nanogram } \\ \mu \mathrm{M} & \text { Micromolar } \\ \mu \mathrm{l} & \text { Microlitres } \\ \mathrm{ml} & \text { Millilitres } \\ \mathrm{mm} & \text { Millimetres } \\ \mathrm{m} & \text { Metres } \\ \mathrm{m}^{3} & \text { Cubic Metres } \\ \mathrm{mg} & \text { Milligrammes } \\ \% & \text { Percent } \\ \text { PCR } & \text { Polymerase Chain Reaction } \\ \mathrm{RAPD} & \text { Random Amplified Polymorphic DNA } \\ \mathrm{rpm} & \text { Revolution Per Minute } \\ \text { TAE } & \text { Tris-acetate Ethlylenediaminetetraacetic Acid } \\ \text { TFPGA } & \text { Tools for Population Genetic Analyses } \\ \text { SE } & \text { Standard Error } \\ \text { UPGMA } & \text { Unweighted Pair Group Method with } \\ & \text { Arithmetic Averages }\end{array}$

\section{References}

[1] Burkill HM, 1985 The Useful Plants of West Africa. Second edition. Royal Botanic Gardens, Kew. Pp. 278-283.

[2] Irvine FR, 1961 Woody Plants of Ghana with Special Reference to their Uses. Oxford University Press. Pg. 191.

[3] Siepel A, Poorter L, Hawthorne WD, 2004 Ecological Profiles of large timber species. In: Biodiversity of West African Forests. Poorter L, Bongers F, Kouame FN, Hawthorne WD (editors). CABI Publishing, Wallingford, UK. Pp 403.

[4] Lobo JA, Quesada M, Stoner KE, 2005 Effects of pollination by bats on the mating system of Ceiba pentandra (Bombacaceae) populations in two tropical life zones in Costa Rica. American Journal of Botany 92: 370-376. DOI: 10.3732/ajb.92.2.370

[5] Dick CW, Birmingham E, Lemes MR, Gribel R, 2007 Extreme long-distance dispersal of the lowland tropical rainforest tree Ceiba pentandra L. (Malvaceae) in Africa and the Neotropics. Molecular Ecology 16: 3039-3049.

[6] Brondani RPV, Gaiotto FA, Missiaggia AA, Kirst M, Gribel R, Grattapaglia D, 2003 Microsatellite markers for Ceiba pentandra (Bombacaceae), an endangered tree species of the Amazon forest. Molecular Ecology Notes 3: 177-179. DOI: $10.1046 / j .1471-8286.2003 .00389 . x$

[7] Williams JW, Jackson ST, Kutzbach JE, 2007 Projected distributions of novel and disappearing climates by $2100 \mathrm{AD}$. Proceedings of the National Academy of Science, USA 104: 5738-5742.
[8] Gillet E, Gomory D, Paule L, 2005 Measuring genetic variation within and among populations at marker loci. In Conservation and Management of Forest Genetic Resources in Europe. Geburek T, Turok J (editors). Arbora Publishers, Zvolen. Pp 237-273.

[9] Vendramin GG, Hansen OK, 2005 Molecular markers for characterizing diversity in forest trees. In Conservation and Management of Forest Genetic Resources in Europe. Geburek T, Turok J (editors). Arbora Publishers, Zvolen. Pp 337-368

[10] Archak S, Gaikwad AB, Gautam D, Rao EVVB, Swamy KRM, Karihaloo JL, 2003 Comparative assessment of DNA fingerprinting techniques (RAPD, ISSR and AFLP) for genetic analysis of cashew (Anacardium occidentale L.) accessions of India. Genome 46: 362-369.

[11] Ofori DA, 2001 Genetic diversity and its implications for the management and conservation of Milicia species. PhD thesis, University of Aberdeen. Pp 47.

[12] Enaberuel LO, Obisesan IO, Okolo EC, Akinwale RO, Aisueni NO, Ataga CD, 2014 Genetic Diversity of Shea Butter Tree (Vitellaria paradoxa C. F. Gaernt) in the Guinea Savanna of Nigeria Based on Morphological Markers. AmericanEurasian J. Agric. \& Environ. Sci., 14 (7): 615-623. DOI: 10.5829/idosi.aejaes.2014.14.07.12365

[13] Grattapaglia D, 2007 Marker-assisted selection in Eucalyptus. In: Current status and future perspectives in crops, livestock, forestry and fish. Guimaraes EP, Ruane J, Scherf BD, Sonnino A, Dargie JD (editors). Food and Agriculture Organization of the United Nations, Rome. Pp 252-281.

[14] Deng C, Zhou J, Gao W, Sun F, Qin R, Lu L, 2006 Assessment of genetic diversity of Lycoris longituba (Amaryllidaceae) detected by RAPDs. Journal of Genetics 85 (3): 205-207.

[15] Monteleone I, Ferrazzini D, Belletti P, 2006 Effectiveness of neutral RAPD markers to detect genetic divergence between the subspecies uncinata and mugo of Pinus mugo Turra. Silva Fennica 40 (3): 391-406.

[16] Brown JKM, 1996 The choice of molecular marker methods for population genetics studies of plant pathogens. New Phytopathology 133: 183-195.

[17] Xia T, Meng L, Mao K, Tian B, Miehe G, Liu J, 2008. Genetic variation in the Qinghai-Tibetan plateau endemic and endangered conifer Cupressus gigantea, detected using RAPD and ISSR markers. Silvae Genetica 57 (2): 85-92.

[18] Lee S, Kim Y, Kim W, 2003 Lack of allozyme and ISSR variation in the Rare endemic tree species, Berchemia berchemiaefolia (Rhamnaceae) in Korea. Annals of Forest Science 60: 357-360 357.

[19] Gupta S, Srivastava M, Mishra GP, Naik PK, Chauhan RS, Tiwari SK, Kumar M, Singh R, 2008 Analogy of ISSR and RAPD markers for comparative analysis of genetic diversity among different Jatropha curcas genotypes. African Journal of Biotechnology 7 (23): 4230-4243.

[20] Egnin M, Mora A, Prakash CS, 1998 Factors enhancing Agrobacterium tumefaciens - Mediated Gene Transfer in peanut (Arachis hypogeal L.). In vitro Cellualar and Developmental Biology of Plants, 34: 310-318. 
[21] Nei M, 1972 Genetic distance between populations. American Naturalist, 106: 283-292.

[22] Nei M, Li W, 1979 Mathematical model for studying genetical variation in terms of restriction endonucleases. Proceedings of the National Academy of Sciences of the United States of America 76 (10): 5269-5273.

[23] Abengmeneng C S, Ofori DA, Kumapley P, Akromah R, Jamnadass R, 2015 Estimation of heritability and genetic gain in height growth in Ceiba pentandra. African Journal of Biotechnology, 14 (22): 1880-1885. DOI: 10.5897/AJB2014.14287

[24] Stacy EA, 2001 Cross-fertility in two tropical tree species: evidence of inbreeding depression within populations and genetic divergence among populations. American Journal of Botany, 88: 1041-1051.
[25] El-Kassaby YA, Cook C, 1994 Female reproductive energy and reproductive success in a Douglas-fir seed orchard and its impact on genetic diversity. Silvae Genetica, 43: 243-246.

[26] Boshier DH, 2000 Mating systems. In: Forest conservation genetics: principles and practice. Young A, Boshier D, Boyle $\mathrm{T}$ (editors). CSIRO Publishing/CABI Publishing, Melbourne/Wallingford. Pp 63-79

[27] Hansson B, Westerberg L, 2002 On the correlation between heterozygosity and fitness in natural populations. Molecular Ecology 11: 2467-2474.

[28] Uyoh EA, Umego C, Aikpokpodion PO, 2014 Genetic diversity in African Nutmeg (Monodora myristica) accessions from South Eastern Nigeria. African Journal of Biotechnology, $13 \quad$ (42): $\quad 4105-4111 . \quad$ DOI: 10.5897/AJB2014.14075 